\title{
INTER-KOREAN SPORTS DIPLOMACY AS A TOOL OF POLITICAL RAPPROCHEMENT
}

\begin{abstract}
The aim of the article is to investigate the issue of sports diplomacy directed at political rapprochement between states in conflict, by the example of relations between North and South Korea. The research is an empirical case study and its objective is either to propose generalizations on the issue of sports diplomacy, and to find characteristics concerning the inter-Korean sports diplomacy. An attempt to test a hypothesis stating that sport can be regarded as a field that allows representatives of hostile countries to engage in a dialogue even if it would not be possible in other fields will be made.

The research has proved the mentioned hypothesis to be plausible. It has been observed, that inter-Korean positive sports diplomacy has been conducted with the use of a number of methods, such as sports exchanges, negotiations concerning sports cooperation including joint participation in sports events and the use of sports events as a circumstance for arranging political talks, what appears to be distinctive for the case. Fluctuations of the intensity of sports cooperation depending on current political relations have also been observed, but on the other hand on some occasions sport allowed the two parties to foster political rapprochement. The effectiveness of sports diplomacy between North and South Korea was therefore evaluated as limited, but identifiable.
\end{abstract}

Keywords: North Korea, South Korea, sports diplomacy, public diplomacy, politics and sport.

\section{INTRODUCTION}

The aim of the article is to analyse one of the significant cases of sports diplomacy oriented at bringing two hostile states closer - between North and South Korea, two countries formally still at war. What is characteristic about this case is that it does not refer to a single event, but to a whole series of sports exchanges and acts of cooperation between the two countries. Inter-Korean sports diplomacy is also fluctuating concerning its intensity, which apparently depends on the current condition of relations between Koreas. It is distinctive about the sports diplomacy between North and South Korea, that cooperation in the field of sport that has occurred between them is very versatile and encompass a whole range of sports exchanges and symbolic gestures. Bearing this in mind, inter-Korean sports diplomacy appears to be a very interesting object of research.

The aim of the article, apart from presenting how sport has been utilized by South and North Korea in order to shape more positive mutual relations, is to test a hypothesis

\footnotetext{
${ }^{1}$ Michał Marcin Kobierecki, PhD, University of Lodz, Faculty of International and Political Studies, e-mail: mkobierecki@uni.lodz.pl.

Dr Michał Marcin Kobierecki, Uniwersytet Łódzki, Wydział Studiów Międzynarodowych i Politologicznych, e-mail: mkobierecki@uni.lodz.pl.
} 
concerning sports diplomacy, according to which sport can be regarded as a field that allows representatives of hostile countries to engage in a dialogue even if it would not be possible in other fields. What is more, an attempt to evaluate the effectiveness of inter-Korean positive (oriented at bringing states closer) sports diplomacy will be made.

The research presented in the article is empirical and has been conducted as a case study concerning sports diplomacy between two states: North and South Korea. In analyzing the case, decision-making method has been employed in order to determine the motivations and determinants of policy-makers.

\section{ORIGINS OF THE INTER-KOREAN SPORTS DIPLOMACY}

Contemporary relations between North and South Korea have been shaped by the events occurring directly after World War II. Earlier in the XXth Century Korean Peninsula was under Japanese occupation, which was finished at the end of World War II after Soviet army liberated Korea from the North US army from the South. This was the basis for the division of the state as Republic of Korea (South Korea) with Syngman Rhee as president was established on 15 August 1948 and Democratic People's Republic of Korea (North Korea) ruled by Kim Il-sung was established on 9 September 1948. A military conflict between the two states broke out in 1950 - a war that engaged such world powers as China and United States. The soldiers ceased to fire in 1953, but the peace treaty was never signed and formally the two Korean states are still at war.

Since their establishment, each of the Korean states was describing itself as the only legal representative of the whole Korean nation. Sport, and the Olympic Movement in particular, was one of the fields of rivalry between the two governments ${ }^{2}$. It worked as a sort of ideological battlefield, what was resulting in numerous boycotts and fierce competition between athletes ${ }^{3}$. At first, this rivalry could be seen in joining the structures of international sport. After the end of World War II Korea began efforts to create National Olympic Committee and to receive recognition by the International Olympic Committee. Already in 1946 Chosun Sports Association - an organization that was banned by the Japanese, was re-established ${ }^{4}$. CSA lobbied the IOC and encouraged Korean sports federations to join international sports federations. This way, and as a result of engaging personal contacts of Korean sports officials, on 20 June 1947 the Republic of Korea was officially accepted as a member of the Olympic Movement, and on 1 July 1947 the Korean Olympic Committee with Yu Ok-kyum as president was officially recognized. As a result, preparations to participate in the Olympic Games in London in 1948 were initiated. Koreans succeeded in sending a team of 69 athletes to the Olympics, where the team competed under the name 'Korea'. As a matter of fact, the country competed already in the Winter Olympics in Sankt Moritz at

${ }^{2}$ B. Bridges, Reluctant Mediator: Hong Kong, the Two Koreas and the Tokyo Olympics, The International Journal of the History of Sport, Vol. 24, No. 3, March 2007, p. 376.

${ }^{3}$ U. Merkel, Sport, Politics and Reunification - A Comparative Analysis of Korea and Germany, The International Journal of the History of Sport, 26:3, 2009, p. 411.

4 J.A. Mangan, H.-D. Kim, A. Cruz, G.-H. Kang, Rivalries: China, Japan and South Korea Memory, Modernity, Politics, Geopolitics - and Sport, The International Journal of the History of Sport, 30:10, 2013, p. 1131. 
the beginning of 1948, where 3 Korean representatives were sent ${ }^{5}$, but for the sake of national prestige Olympic Summer Games were much more important. In the same year though, the division of Korea was confirmed by the formal establishment of the two countries, while the re-established sports structures were associated with South Korea.

Since 1948 North Korea was trying to join the Olympic Movement, but the IOC stood on the position that one state (as Korea was regarded) can only have one NOC. Nevertheless, since the 1950s communist states were lobbying international sports structures in favour of North Korea. The IOC insisted, that if DPRK was to participate in the Olympic, it has to be within a common, inter-Korean team. Negotiations did not go according to IOC's intentions and only South Korean athletes competed in the Olympics in Rome ${ }^{6}$. North Korean efforts to integrate with international sport and the Olympic Movement in particular are very similar to the case of another communist country established after World War II East Germany. The International Olympic Committee refused to accept it as an independent member of the Olympic Movement either, referring to the same principle: one country one National Olympic Committee.

As a result of the support of communist countries, North Korea was eventually recognized by the IOC in 1962, but it could participate in the Olympics only if it created an unified Olympic team with the other Korean state. South Korea opposed, but then the International Olympic Committee threatened it that it would allow North Korea to participate in the Olympics individually. This way negotiations under the support of the IOC began in Lausanne in 1963. In February 1963 initial agreement was achieved, but a problem concerning the design of a common flag remained. Subsequent talks were to be held in Hong Kong, but without the support of International Olympic Committee. The first round of those talks was relatively successful, but the second one was very quickly broken off as both sides accused each other of lack of goodwill. Later the IOC still tried to create a unified Korean team for the Olympics in Tokyo in 1964, but the South Korean government appeared to be reluctant to such settlement. Under such circumstances the International Olympic Committee even threatened that it could only allow North Korea to compete in Tokyo, but South Korean NOC argued that it was legally recognized and it participated in former Olympics. Soon a view that both Korean states should participate in the Olympics individually if the negotiations fail began to dominate. Such was the final decision, as both the IOC and the Japanese hosts of the Games wanted North and South Korean athletes to compete, although a unified team was preferred ${ }^{7}$. This way North Korea for the first time sent its athletes to Olympic Summer Games in 1964. In the end though, the country withdrew its team from the Olympics after a few of its athletes were disqualified in accordance to their participation in GANEFO event, even though its representatives were already in Tokyo ${ }^{8}$. Despite that, from 1964 there were two fully-fledged Korean states in international sport. Unfortunately, in political and diplomatical apsects this resulted most often in fierce ideological competition. For example in 1966, when North Korea forwarded to Football World Cup quarterfinal after defeating favourable Italian team in the group stage, the North Korean regime got a chance to present its superiority over the southern neighbour. As a matter of fact, the South

5 B. Brides, London Revisited: South Korea at the Olympics of 1948 and 2012, The International Journal of the History of Sport, Vol. 30, No. 15, 2013, p. 1824-1825.

${ }^{6}$ B. Bridges, Reluctant Mediator..., p. 377-378.

7 Ibidem, p. 376, 379, 382-384.

${ }^{8}$ Ibidem, p. 375, 385. 
Korean leaders perceived that as a political challenge and this is when this country began to invest heavily in elite sport, what was meant to grant more medals in international competition ${ }^{9}$.

Inter-Korean negotiations from 1963 are regarded as one of the causes of the establishment of sports exchanges between North and South Korea in the future ${ }^{10}$. It should also be noted, that it was one of very few cases of direct talks and attempts to cooperate between North and South Korea at the time. As a result, it can be perceived as one of the proves for the view concerning the capability of sport to overcome diplomatic barriers. Apparently, it is easier for representatives of conflicted states to sit to negotiations on joint participation in seemingly non-political sports event than on other issues.

Throughout 1950s and 1960s there were almost no sports exchanges between North and South Korea, as a result of mutual hostility after the recent war. The unsuccessful negotiations concerning a joint team for the Tokyo Olympics, and earlier for the Games in Rome, were the only exceptions. In 1970s there was also an initiative to create a unified team for the table tennis World Championships held in Pyongyang, but just as before there was no consensus ${ }^{11}$.

The inter-Korean ideological competition in the field of sport in an indirect way eventually began to create an opportunity for establishing sports cooperation between the two countries. Most of all it was related to hosting sports events, which South Korea decided to use for the sake of international image and prestige, and to hit North Korea. Asian Games held in Seoul in 1986 was the first sports mega-event organized by Republic of Korea, although even before the city was selected as the host of this competition, it was also chosen by the International Olympic Committee as the host of the Olympic Summer Games in 1988.

Seoul was to organize Asian Games already in 1970, but in 1968 South Korean government decided to withdraw funding and as a result Seoul resigned from organizing the event, officially as a result of a safety threat from North Korea and the recent political turmoil in the country ${ }^{12}$. In the end, the first Asian Games in Korea were held 16 years later. Interestingly, North Korean capital also applied to host this event, but it appeared to be a political play-acting rather than authentic desire to host the Games by North Korea. In the end, when the chances of Seoul to be selected got fatter after it was also chosen as the host of 1988 Olympic Games, Pyongyang withdrew its bid in fear of losing directly to South Korean capital $^{13}$.

After Seoul was officially selected as the host of Asian Games in 1986, North Korean government decided to disturb the event using such methods as boycott and terrorism. On 14 September 1986, a week before the opening of the Asian Games, a bomb exploded at the Gimpo airport in Seoul. 5 people were killed and more than 30 were injured. As it has

\footnotetext{
9 J.W. Lee, Do the scale and scope of the event matter? The Asian Games and the relations between North and South Korea, Sport in Society, 2015, p. 3-4.

${ }^{10}$ K.-G. Yu, S.-Y. Park, Selection and concentration strategy in the sports exchange between North and South Korea, Journal of Asian Public Policy, 8:2, 2015, p. 225.

11 Ibidem, p. 217.

${ }^{12}$ E. Koh, South Korea and the Asian Games: The First Step to the World, Sport in Society, 8:3, 2005, p. 474; J.W. Lee, Do the scale and scope..., p. 5.

${ }^{13}$ Ibidem.
} 
been confirmed later, North Korean agents were responsible for the bombing ${ }^{14}$. The boycott was obviously conducted by DPRK, but also by a few other states, such as Syria, Myanmar, Vietnam, Lao, Cambodia, Mongolia and South Yemen ${ }^{15}$, but authors differ concerning the actual reasons of boycotts by particular countries. There was no inter-Korean cooperation, but such opportunity was to appear more strongly in reference to the Seoul Olympics two years later.

\section{SIGNIFICANCE OF SEOUL 1988 OLYMPIC GAMES}

According to Victor Cha, the Olympics in Seoul 'meant essentially game over in the inter-Korean competition for legitimacy in the world ${ }^{16}$, as South Korea demonstrated the level of development that North Korea was not able to equal. Therefore the Games were a problem to North Korean, which tried to intimidate members of the IOC who would back the Seoul bid and to besmirch South Korea and its capital, and even proposed Greece as the permanent host of the Olympics ${ }^{17}$. Then, as the Games were approaching, a chance for cooperation and utilizing sport for the sake of political rapprochement between the two Koreas appeared, as North Korea declared the desire to co-host the Olympics. Initially it demanded that half of the competitions should be held in the North. This North Korean declaration complicated the situation in the Olympic Movement. It must be born in mind, that North Korea was not recognized as 37 countries with fully legitimate National Olympic Committees ${ }^{18}$. What is more, the idea did not apply to the principles of the Olympic Charter and the agreements between the IOC and the organizing committee of the Seoul Olympics. Also, the whole concept appeared highly infeasible simply as a result of internal security policy of Pyongyang which restricted the visits of foreigners. Despite all this, the president of the International Olympic Committee Juan Antonio Samaranch decided to enter into dialogue with North Korean regime, in order to stabilize the situation.

A number of meetings between North and South Korea was organized, with the IOC as a mediator. First 3 of them were held in Panmunjom at the border between two Koreas in April and May 1984, while the next ones in Lausanne in Switzerland. North Korean negotiators were making various demands, for instance that 2 simultaneous opening ceremonies should be held in both Korean states, or that the whole Olympic football tournament should be played in the North. The also demanded a unified Korean team at the Olympics. The postulate of the freedom to travel between the North and South of Korean Peninsula for the

14 Ibidem.

15 C. Choi, M. Shin, C.-G. Kim, Globalization, Regionalism and Reconciliation in South Korea's Asian Games, The International Journal of the History of Sport, 32:10, 2015, p. 1311, J.W. Lee, Do the scale and scope..., p. 6; R. Harvey, Seoul Opens Its Heart and Its Heavens, Too, as Asian Games Begin, Los Angeles Times, 21.09.1986, http://articles.latimes.com/1986-09-21/sports/ sp-8947_1_north-koreans (access: 14.07.2016 r.).

16 V.D. Cha, Beyond the Final Score. The Politics of Sport in Asia, Columbia University Press, New York 2009, s. 59-60.

17 J.A. Mangan , G. Ok, K. Park, From the destruction of image to the reconstruction of image: a sports mega-event and the resurgence of a nation - the politics of sport exemplified, The International Journal of the History of Sport, 28:16, 2011, p. 2352-2353.

18 A. Guttmann, The Olympics. A History of Modern Games, University of Illinois Press, Urbana 2002, p. 165, D. Miller, Historia Igrzysk Olimpijskich i MKOl. Od Aten do Pekinu 1894-2008, Rebis, Poznań 2008, p. 290. 
accredited athletes, officials, journalists and tourists appeared to be unachievable though. J.A. Samaranch offered Pyongyang hosting a few archery and table tennis competitions and parts of the cycling and football contests. The negotiations were still being held in 1987 . North Korea was offered another concession - a proposition to host women volleyball tournament. In the end there was no agreement though, as North Korea withdrew from the talks after the IOC set a deadline for the final deal for September 1987 - the time when invitations to National Olympic Committees to the Games were to be sent. The DPRK negotiators informed, that the concessions that they had been offered are not enough. There were fears that North Korean regime may try to interrupt the event, but at the same time it appeared improbable taking into consideration that athletes and officials from communist states were present in Seoul ${ }^{19}$.

In the end, North Korea boycotted the Olympic Games in Seoul - in protest against not being made its co-host. Similarly as two years earlier, a few states did not send its athletes to Seoul in support to Pyongyang: Cuba, Ethiopia and Nicaragua ${ }^{20}$. However, despite the failure of the negotiations and another boycott of the sports event held in South Korea by its northern neighbour, it was another situation when North and South Koreans sat to negotiate, thus supporting the hypothesis about sport as an area in which hostile political units are more eager to enter into dialogue, even if in fact none of the parties is fully interested in cooperation.

\section{UNIFIED KOREAN TEAM}

Asian Games in 1990 in Beijing is another sports event relevant in analysing positive sports diplomacy between North and South Korea. The Games were being held at the time when South Korea generally was searching for a way to enhance its relations with communist states, within so called Nordpolitik. At the same time China's intention was to organize successful sports event. As a result, Republic of Korea decided to share its experience and know-how on organizing Asian Games with the Chinese, in hope of opening new diplomatic channels with PRC, what eventually happened ${ }^{21}$. North Koreans were opposing such cooperation, but either way Beijing accepted South Korean assistance ${ }^{22}$.

This situation had a clear effect on the relations between the two Koreas. Rapprochement between a foe (South Korea) and an ally (China) obviously constituted a problem for DPRK. Therefore, in fear of isolation, North Korea proposed inter-Korean talks on the possibility of creating a joint Korean team that would participate in the Asian Games in Beijing. Despite being suspicious about the true intention of Pyongyang, South Korean authorities decided to enter into dialogue. Negotiations were held from March 1989 until February 1990. They resulted in decisions on the name of the team, the flag with a shape of Korean Peninsula and the use of traditional Korean folk song Arrirang as an anthem of the joint team. However, despite those successes, a unified team was not formed at the time. South

${ }^{19}$ Ibidem, p. 290-291; R. Palenski, Seoul 1988 [in:] J.E. Findling, K.D. Pelle, Encyclopedia of the Modern Olympic Movement, Greenwood Press, Westport 2004, p. 219; A. Guttmann, The Olympics..., p. 165-166.

20 Seoul 1988, https://www.olympic.org/seoul-1988 (access: 14.07.2016 r.).

21 J.W. Lee, Do the scale and scope..., p. 6.

${ }^{22}$ V. Cha, The Asian Games and Diplomacy in Asia: Korea-China-Russia, The International Journal of the History of Sport, 30:10, 2013, p. 1184. 
Korea demanded, that the selection of athletes should take place as early as possible and that joint trainings should be organized, whereas North Korea did not want to agree until South Korea promised it would not participate in the Games individually under no circumstances. Then again, South Korea feared that its Northern neighbour would withdraw from the event. This way, both Koreas participated in the Beijing Asian Games separately ${ }^{23}$.

The negotiations that North and South Korea conducted before the 1990 Asian Games can be regarded as another example when two states in conflict undertook talks concerning the eventual cooperation in sport, but their diplomatic relevance was much greater. Negotiators managed to agree upon the common national symbols, which were actually used by the fans form both Koreas, who cooperated during the Games ${ }^{24}$. In the future, those symbols were to be used during more successful efforts of inter-Korean cooperation during sports mega-events, but the case of collaboration between fans from both Korean states should also be stressed. This seems to be an exemplary case of positive sports diplomacy perceived as an element of public diplomacy, at the same time being an argument supporting the view about no hostility between ordinary people from the two Korean states and both societies' readiness for the possible breakthrough in mutual political relations.

The inter-Korean negotiations that have been initiated before the Beijing 1990 Asian Games, were continued, despite their failure. Already in Beijing, Chinese government mediated during the talks, which ended in an agreement on organizing friendly football matches in Seoul and Pyongyang ${ }^{25}$. Football 'unification matches', as they have been described, were held in October 1990 in both states' capitals and constituted first such exchange ${ }^{26}$, although according to Dan Sanford, athletes from North Korea had been invited to participate in at least three competitions in the South already in Summer $1989^{27}$. Soon, new sports exchanges were arranged and in 1991 eventually a joint team was created for table tennis World Championships in 1991.

The 1991 table tennis championships held in Japanese Chiba resulted in a historic victory by unified Korean team, as a women's double team representing both nations won gold medal ${ }^{28}$. It is worth noting, that during the negotiations concerning participation in the event North and South Korea could not reach a consensus on the location on training camp and in the end athletes had 40 days of joint training sessions in Japan immediately before the championships $^{29}$. Creating a joint team for the event was a breakthrough in the mutual sports cooperation between two Koreas, as for the first time diplomatic negotiations on creating joint team for a sports event succeeded.

Similarly as during the historic 1991 table tennis World Championships, North and South Korea managed to create an unified team for the junior football World Championships held in Portugal in $1991^{30}$. Unfortunately, there was a serious deterioration of interKorean relations shortly after. This resulted in limitation of cooperation in sports. Relatively

23 J.W. Lee, Do the scale and scope..., p. 6-7.

24 Ibidem, p. 8.

25 Ibidem.

${ }^{26}$ U. Merkel, Sport, Politics and Reunification..., p. 415.

${ }^{27}$ D.C. Sanford, South Korea and the Socialist Countries. The Politics of Trade, MacMillan Press, Basingstoke 1990, p. 58.

28 J.W. Lee, Do the scale and scope..., p. 4.

${ }^{29}$ U. Merkel, Sport, Politics and Reunification..., p. 413.

30 Z. Mateša, Wydarzenia sportowe jako kluczowy element przełamywania barier [in:] Sport i Dyplomacja, Polski Komitet Olimpijski, Warszawa 2015, p. 28. 
positive sports relations got worse after South Korean judoka won with its North Korean opponent in July 1991. The political tension grew even higher in 1993, when North Korea withdrew from treaty on non-proliferation of Nuclear weapon ${ }^{31}$.

The sports cooperation between North and South Korea from the very beginning was in a way a reflection of political relations. In this sense we should agree with Jung Woo Lee, who claims that 'sport functions as a barometer to measure the political relations between the two Koreas' ${ }^{32}$. The success of negotiations concerning the creation of joint teams for the selected international sports events at the beginning of 1990s should then be associated with compromise-oriented policy of South Korean president Roh Tae-woo (in office between 1988 and 1993) - the already mentioned Nordpolitik. This resulted in a dialogue which led to signature of Agreement on Reconciliation, Non-Aggression, and Exchanges and Cooperation in 1991 and Declaration on the Denuclearization of the Korean Peninsula in 1992. Nevertheless, the détente tendencies got reversed, thus resulting in limitation of sports cooperation and exchanges.

\section{JOINT PARTICIPATION IN OPENING CEREMONIES OF SPORTS EVENTS}

Another shift in inter-Korean relations happened at the end of 1990s, this time as a result of so called Sunshine Policy pursued by South Korean president between 1998-2003 Kim Dae-jung. The longest period of cooperation and exchanges in sport between North and South Korea so far began at the time. In December 1999 North Korean national team in basketball played in South Korea a series of 4 matches. This was the first sports visit of North Koreans in Republic of Korea in 9 years. The North Korean team was welcomed very warmly, while president Kim Dae-jung stated that 'sports exchanges could become the fastest path to work for reconciliation and mutual understanding between the two Koreas' ${ }^{33}$. This type of international cooperation became a very important diplomatic method in the era of Sunshine Policy.

The concept of joint participation of national teams of both Koreas in opening ceremonies of sports events including Olympic Games, with simultaneous independent participation in those events, was one of the most remarkable effects of the rapprochement. This was achieved for the first time during the Olympic Summer Games in Sydney in 2000. During the opening ceremony, athletes from North and South Korea marched together dressed in the same uniforms under a white flag with deep blue shape of Korean Peninsula ${ }^{34}$. This occurrence is often described as a direct consequence of a meeting between South Korean president Kim Dae-jung and Kim Jong-il in North Korea ${ }^{35}$. There were comments about the cooperation, that it was 'creating a new hope for peace and progress on the Korean peninsula' ${ }^{36}$. Two Koreas cooperated earlier in the field of sport, including creating unified team

\footnotetext{
31 J.W. Lee, Do the scale and scope..., p. 8.

${ }^{32}$ Ibidem, p. 2.

33 J. Goldberg, Sporting diplomacy: Boosting the size of the diplomatic corps, The Washington Quarterly, 23:4, 2000, p. 68-69.

${ }^{34}$ U. Merkel, The Politics of Sport and Identity in North Korea [in:] F. Hong, L. Zhouxiang, Sport and Nationalism in Asia. Power, Politics and Identity, Routledge, London 2015, p. 111.

35 C. Choi, M. Shin, C.-G. Kim, Globalization, Regionalism and Reconciliation..., p. 1314.

${ }^{36}$ H. Pan, Asian Sport: Its Athletic Progress and Social Integration, The International Journal of the History of Sport, 29:4, 2012, p. 559.
} 
for a particular event, but never before had it been cooperation during the Olympics, which is the most important mega-event of the contemporary sport.

Asian Games in South Korean Busan, taking place 2 years after the Olympics in Sydney, for the second time on the South Korean soil, were very important within the inter-Korean sports diplomacy, which apparently was flourishing again. The declared objectives of the event were strengthening of friendship of Asian nations, expanding their exchanges and boosting their community spirit ${ }^{37}$. They all imply a possibility of utilisation of the event for the sake of political rapprochement between South and North Korea and apparently such was the practical execution of the event.

As one of the aims of the Busan Games' organizing committee was to expose conciliation between Koreas, in 2001 it issued and invitation to participate in the event to North Korea. Initially the North responded negatively claiming that sending so many athletes to South Korea as politically risky, but after a number of inter-Korean talks in September 2002 the invitation has been accepted. After 2 additional meetings aimed to discuss logistical issues, North Korea informed about its decision to send 318 athletes, 22 state officials and 355 cheerleaders to the Busan Games ${ }^{38}$, although the exact figures differ according to different authors. The cheerleaders, which were described as the 'cheering squad of beauties', were gaining attention and sympathy of South Koreans. It should also be noted, that it was the first time North Korea participated in a sports event in the South since the two Koreas separated $^{39}$. In the past, DPRK boycotted every single sports event organized by Republic of Korea, as a result of not recognizing the existence of its southern neighbour. The situation eventually changed as a result of inter-Korean summit in 2000, when the North Korean regime accepted the existence of 2 separate governments on the Peninsula ${ }^{40}$.

During the Busan 2002 Asian Games, similarly as at the Olympics in Sydney, North and South Korean athletes participated in the opening ceremony together, dressed similarly and marching under white flag with the shape of Korean Peninsula, although without the Olympic circles. The reconciliation symbolism was all around, with ignition of the Asian Games torch on the top of mount Baekdu in North Korea and its handover to South Korea on the southern slope of mount Kumgang. The first of the mounts is associated with Korean national identity, while the second was the only place open by the North Korean government for the tourists from South Korea. Athletes from both countries also marched together during the closing ceremony, while the North Korean cheerleaders supported not only Koreans from the North, but also from the South. The Asian Games flame was lighted by two athletes together - one from North and one from South Korea. The reconciliation symbolism was all-embracing then, so no surprise the event is sometimes described as 'the Games of reconciliation between North and South Korea' ${ }^{41}$.

The inter-Korean sports cooperation was flourishing since the launch of the South Korean Sunshine Policy. Athletes from both countries, similarly as during the Sydney Olym-

${ }^{37}$ C. Choi, M. Shin, C.-G. Kim, Globalization, Regionalism and Reconciliation..., p. 1312.

38 J.W. Lee, Do the scale and scope..., p. 9.

39 C. Choi, M. Shin, C.-G. Kim, Globalization, Regionalism and Reconciliation..., s. 1313-1314.

40 J.W. Lee, Do the scale and scope...

${ }^{41}$ J.W. Lee, Do the scale and scope..., p. 8-9; U. Merkel, North Korean Media Accounts of the Olympic and Asian Games: The Fatherland's Friends and Foes, The International Journal of the History of Sport, 29:16, 2012, p. 2331, C. Choi, M. Shin, C.-G. Kim, Globalization, Regionalism and Reconciliation..., s. 1314. 
pics, marched together at opening ceremonies of Olympic Games in Athens in 2004 and Torino in $2006^{42}$, as well as during Asian Winter Games in Chinese Changchun in $2007^{43}$. There were also many sports exchanges between the two countries, such as North and South Korean basketball teams' visits in Seoul and Pyongyang in 1999 or the friendly table tennis match in Seoul in $2000^{44}$. In 2000 a first unification basketball tournament was organized in the capital cities of both states, with men and women all-stars teams. The matches in Pyongyang were the first sports events in North Korea broadcasted by television. Cooperation encompassed a sort of development aid as well, for example in 2005 South Korea provided football equipment to North Korea. In November 2005150 marathon runners participated in a Unification Marathon Pyongynag-Nampho in North Korea. In the next year a friendly match in women's hockey was organized, and as a goodwill gesture Hwang Bo Young, who defected from North Korea at the age of 19, was not allowed to play for the South. After a month, another hockey exchange was conducted. This time two mixed women's teams were created, called uri which means 'we' and hana which means 'one'. As another unification symbol of the exchange, North Korean players travelled to the South through the Tonghae route, for the first time by land. There were also more grassroots' exchanges, for example Kangwon province which shared border with North Korea organized o few exchanges, such as invitation of North Korean kids to participate in 'Dream Programme' in 2007, which donates Winter sports equipment ${ }^{45}$. As can be seen, inter-Korean sports diplomacy directed at political rapprochement peaked in the middle of the first decade of XXIst Century. This could be seen either in joint marches during various sports mega-events and in numerous sports exchanges.

As the inter-Korean cooperation in the field of sport was developing very well, a concept that both states should compete together during the Olympic Games in Beijing in 2008 appeared. In November 2005 an initial agreement was even made, what can be regarded as another, symbolic step towards reconciliation. As one of the officials of South Korean Unification Ministry said in an interview in May 2006, it would 'serve as a symbol of reconciliation and cooperation'. The initiative was also supported by the International Olympic Committee $^{46}$. Nevertheless, despite negotiations being held almost till the beginning of the Games, the initiative did not succeed - as a result of failing to compromise concerning the method of selection of athletes. The North desired an even representation of both states, while the South opted for selecting representatives concerning their achievements. Still, the declaration of intention to create a joint Olympic team itself was regarded as a diplomatic success and a signal of North Korean edging out of isolation ${ }^{47}$.

Directly before the Beijing Olympics, the relations between North and South Korea got worsened as a result of resignation from Sunshine Policy by new South Korean president

${ }^{42}$ Z. Mateša, Wydarzenia sportowe jako kluczowy element...

${ }^{43}$ C. Choi, M. Shin, C.-G. Kim, Globalization, Regionalism and Reconciliation...

44 J.W. Lee Do the scale and scope..., p. 9.

45 U. Merkel, Sport, Politics and Reunification..., p. 415-416.

${ }^{46}$ U. Merkel, Bigger than Beijing 2008. Politics, Propaganda, and Physical Culture in Pyongyang [in:] J.A. Mangam, F. Hong, Post-Beijing 2008. Geopolitics, Sport and the Pacific Rim, Routledge, London 2011, p. 145.

${ }^{47}$ U. Merkel, The Politics of Sport and Identity in North Korea [in:] F. Hong, L. Zhouxiang, Sport and Nationalism in Asia. Power, Politics and Identity, p. 111; U. Merkel, Sport, Politics and Reunification..., p. 414, U. Merkel, The Politics of Sport and Identity in North Korea, The International Journal of the History of Sport, 31:3, 2014, p. 383; U. Merkel, North Korean Media..., p. 2327. 
Lee Myung-bak and with regard to the death of South Korean tourist shot by North Korean soldier near Mount Kumgang in July 2008. As a result, two Korean states did not even march together during the opening ceremony ${ }^{48}$. The period of flourishing positive interKorean sports diplomacy was thus over.

\section{NEW ATTEMPTS TO INTER-KOREAN SPORTS DIPLOMACY}

A chance to utilise sport for the sake of shaping positive relations between North and South Korea appeared again in 2014, in respect to the third Asian Games held on South Korean soil - in Incheon. This was the time of a mild rapprochement between the two states, after deterioration in mutual relations caused by inter alia joint USA-South Korea military exercises $^{49}$, as well as military provocations by North Korea in 2010 including torpedo attack on one of South Korean navy ships and a firing on one of South Korean islands. In 2011 North Korean leader Kim Jong-il passed away and his son Kim Jong-un took over, what resulted in even more aggressive behaviour towards southern neighbour in order to display political stability of the new regime. Despite all this, North Korea expressed the readiness to send a team to the Games and offered talks concerning the issue, what South Korea accepted. The negotiations were difficult though. North insisted that South should finance the visit by cheerleaders, while South disagreed both to this and to using oversized North Korean flags. The North even declared re-considering its will to send athletes to the Games, but in the end decided to send a team, but without the cheerleaders, against the expectations of the hosts ${ }^{50}$.

As a result of worse relations between two Koreas, Asian Games in Incheon lacked reconciliation symbolisms that was present during the event in Busan. There was no joint march during the opening ceremony and North Korean national symbols could not be displayed publicly. Even the possibility to use of unification flag with Korean Peninsula was limited $^{51}$. Nonetheless, the final of football tournament, when North and South Korean teams met (South Korea won), had positive symbolism ${ }^{52}$. Fans of both teams yelled slogans like 'Let us become one and startle the world', 'Reunify the Fatherland', 'Whichever team may win, we are one', 'A unified Korean team is the best in the world' ${ }^{53}$. It was another case when people of two conflicted Korean states expressed mutual sympathy, thus disclosing the artificiality of the political division of the Korean Peninsula.

During the Asian Games in Incheon, a few high-profile North Korean officials, including general political director of the military Byeong-Seo Hwang, party secretary Ryong-Hae Choi and secretary in charge of relations toward South Korea Yang-Geon Kim travelled South Korea to watch the event. During their visit, they met with representatives of

${ }^{48}$ U. Merkel, The Politics of Sport and Identity in North Korea [in:] F. Hong, L. Zhouxiang, Sport and Nationalism in Asia. Power, Politics and Identity...

${ }^{49}$ L. Yin, A Review of the Strategic Situation on the Korean Peninsula [in:] Institute for Strategic Studies, National Defense University of People's Liberation Army, International Strategic Relations and China's National Security, Vol. 1, World Scientific, Singapore 2015, s. 225.

50 J.W. Lee, Do the scale and scope..., p. 10-11; C. Choi, M. Shin, C.-G. Kim, Globalization, Regionalism and Reconciliation..., p. 1316.

51 J.W. Lee, Do the scale and scope..., p. 11.

${ }_{52}$ C. Choi, M. Shin, C.-G. Kim, Globalization, Regionalism and Reconciliation..., p. 1314.

${ }^{53}$ D.H. Van Tassell, D.A. Terry, An overlooked path to peace and stability: sport, the state and the case of the Koreas, Sport in Society, 15:6, 2012, p. 816. 
South Korean government and returned to DPRK after watching the closing ceremony. This was the first visit of such high-profile leaders of the North in an international event in South Korea $^{54}$. Once they were in Incheon, South Korean government issued an invitation to meet, which was accepted. The two parties agreed upon organizing high-level talks in October or at the beginning of November, in order to fix the current political impasse ${ }^{55}$. A form of sports diplomacy known from relations between India and Pakistan (cricket diplomacy) or Turkey and Armenia (football diplomacy) occurred then. In this contest, sports event constitutes an opportunity for politicians representing conflicted states to hold diplomatic talks which otherwise would probably be way more difficult to arrange.

\section{CONCLUSIONS}

North and South Korea utilized sport in order to pursue diplomatic dialogue in a number of ways. Review of particular cases allows to state, that in comparison to other cases of sports diplomacy aimed at political rapprochement between states, the inter-Korean case was and still is conducted in various different ways. It encompass sports exchanges on various levels - from elite sport to sport of children and youth, negotiations concerning the joint participation in sports events, and lately even using sports events as a circumstance for arranging political talks. This diversity of methods within inter-Korean positive sports diplomacy is one of its main distinctive features.

A characteristic fluctuation of the intensity of sports exchanges and cooperation between North and South Korea has been observed, what on the other hand pertains to the secondary character of sports relations in respect to political relations. As has been pointed, inter-Korean sports diplomacy directed at bringing the two states closer flourished in the times of political détente, while being suppressed when political relations deteriorated. It does not mean though, that the use of sport by two Koreas in order to shape positive bilateral relations was completely useless. There were occasions, when due to sport Koreans from North and South were able to initiate negotiations, what could often be difficult if it was not about sport. Inter-Korean sports diplomacy should therefore be regarded as a subsidiary tool of shaping mutual relations, with limited but identifiable effectiveness.

It is often stated, that Koreans from North and South share common ethnicity and culture. Nevertheless, hostility and reluctance to dialogue remain as dominating attitudes. It appears though, that the enmity of the elites is not representative for the societies, what could be seen in the behaviour of sports fans from both Koreas during sports events, who often cooperated. In this context inter-Korean sports diplomacy could be compared to famous USA-China ping-pong diplomacy, which inter alia showed that both Chinese and American societies were ready for a breakthrough in bilateral relations. Inter-Korean sports diplomacy appears to give policymakers the same lesson.

According to Udo Merkel, one of the aims of pursuing sports diplomacy between North and South Korea is to remain the issue of reunification in the political discourse without the need to conduct difficult negotiations ${ }^{56}$, as unification remains a key objective for both

${ }^{54}$ C. Choi, M. Shin, C.-G. Kim, Globalization, Regionalism and Reconciliation..., p. 1316-1317.

55 J.W. Lee, Do the scale and scope...

${ }^{56}$ U. Merkel, G. Ok, Identity Discourses in North Korean Events, Festivals and Celebrations [in:] U. Merkel, Identity Discourses and Communities in International Events, Festivals and Spectacles, red., AIAA, Basingstoke 2015, p. 137 
Koreas. In the current geopolitical situation, the unification of North and South Korea appears to be highly improbable though, as none of its possible scenarios seems acceptable to any of the parties. Bearing this in mind, it is difficult to predict the future developments of inter-Korean sports diplomacy, just as it is hard to anticipate the political developments. According to Kwang-Gil Yu and Seong-Yong Park, joint organization of a sports event would probably have positive effect on the inter-Korean relations ${ }^{57}$. It is hard not to agree with this view, such was one of the aims of co-hosting football World Cup by South Korea and Japan in 2002, two states with negative historical experiences still present in collective memory of Koreans. Still, taking into consideration political isolation of North Korea, such scenario remains highly improbable either.

\section{REFERENCES}

1. Brides B., London Revisited: South Korea at the Olympics of 1948 and 2012, The International Journal of the History of Sport, Vol. 30, No. 15, 2013.

2. Bridges B., Reluctant Mediator: Hong Kong, the Two Koreas and the Tokyo Olympics, The International Journal of the History of Sport, Vol. 24, No. 3, March 2007.

3. Cha V.D., Beyond the Final Score. The Politics of Sport in Asia, Columbia University Press, New York 2009.

4. Cha V., The Asian Games and Diplomacy in Asia: Korea - China - Russia, The International Journal of the History of Sport, 30:10, 2013.

5. Choi C., Shin M., Kim C.-G., Globalization, Regionalism and Reconciliation in South Korea's Asian Games, The International Journal of the History of Sport, 32:10, 2015.

6. Goldberg J., Sporting diplomacy: Boosting the size of the diplomatic corps, The Washington Quarterly, 23:4, 2000.

7. Guttmann A., The Olympics. A History of Modern Games, University of Illinois Press, Urbana 2002.

8. Harvey R., Seoul Opens Its Heart and Its Heavens, Too, as Asian Games Begin, Los Angeles Times, 21.09.1986, http://articles.latimes.com/1986-09-21/sports/sp-8947_1_north-koreans (access: 14.07.2016 r.).

9. Koh E., South Korea and the Asian Games: The First Step to the World, Sport in Society, 8:3, 2005, pp. 468-478.

10. Lee J.W., Do the scale and scope of the event matter? The Asian Games and the relations between North and South Korea, Sport in Society, 2015.

11. Mangan J.A., Kim H.-D., Cruz A., Kang G.-H., Rivalries: China, Japan and South Korea - Memory, Modernity, Politics, Geopolitics - and Sport, The International Journal of the History of Sport, 30:10, 2013.

12. Mangan J.A., Ok G., Park K., From the destruction of image to the reconstruction of image: a sports mega-event and the resurgence of a nation - the politics of sport exemplified, The International Journal of the History of Sport, 28:16, 2011.

13. Mateša Z., Wydarzenia sportowe jako kluczowy element przełamywania barier [in:] Sport i Dyplomacja, Polski Komitet Olimpijski, Warszawa 2015.

\footnotetext{
${ }^{57}$ K.-G. Yu, S.-Y. Park, Selection and concentration strategy..., p. 225.
} 
14. Merkel U., Bigger than Beijing 2008. Politics, Propaganda, and Physical Culture in Pyongyang [in:] J.A. Mangam, F. Hong, Post-Beijing 2008. Geopolitics, Sport and the Pacific Rim, Routledge, London 2011.

15. Merkel U., North Korean Media Accounts of the Olympic and Asian Games: The Fatherland's Friends and Foes, The International Journal of the History of Sport, 29:16, 2012.

16. Merkel U., Ok G., Identity Discourses in North Korean Events, Festivals and Celebrations [in:] U. Merkel, Identity Discourses and Communities in International Events, Festivals and Spectacles, AIAA, Basingstoke 2015.

17. Merkel U., Sport, Politics and Reunification - A Comparative Analysis of Korea and Germany, The International Journal of the History of Sport, 26:3, 2009.

18. Merkel U., The Politics of Sport and Identity in North Korea [in:] F. Hong, L. Zhouxiang, Sport and Nationalism in Asia. Power, Politics and Identity, Routledge, London 2015.

19. Merkel U., The Politics of Sport and Identity in North Korea, The International Journal of the History of Sport, 31:3, 2014.

20. Miller D., Historia Igrzysk Olimpijskich i MKOl. Od Aten do Pekinu 1894-2008, Poznań 2008.

21. Palenski R., Seoul 1988 [in:] J.E. Findling, K.D. Pelle, Encyclopedia of the Modern Olympic Movement, Greenwood Press, Westport 2004.

22. Pan H., Asian Sport: Its Athletic Progress and Social Integration, The International Journal of the History of Sport, 29:4, 2012.

23. Sanford D.C., South Korea and the Socialist Countries. The Politics of Trade, MacMillan Press, Basingstoke 1990.

24. Seoul 1988, https://www.olympic.org/seoul-1988 (access: 14.07.2016 r.).

25. Van Tassell D.H., Terry D.A., An overlooked path to peace and stability: sport, the state and the case of the Koreas, Sport in Society, 15:6, 2012.

26. Yin L., A Review of the Strategic Situation on the Korean Peninsula [in:] Institute for Strategic Studies, National Defense University of People's Liberation Army, International Strategic Relations and China's National Security, Vol. 1, World Scientific, Singapore 2015.

27. Yu K.-G., Park S.-Y., Selection and concentration strategy in the sports exchange between North and South Korea, Journal of Asian Public Policy, 8:2, 2015.

\section{FUNDING}

1. The research has been financed by National Science Centre, Poland, within project number 2015/19/D/HS5/00513.

\section{DYPLOMACJA SPORTOWA POMIECDZY DWOMA PAŃSTWAMI KOREAŃSKIMI JAKO NARZĘDZIE ZBLIŻENIA POLITYCZNEGO}

Celem badania podjętego w artykule jest zbadanie zagadnienia dyplomacji sportowej ukierunkowanej na polityczne zbliżenie pomiędzy skonfliktowanymi państwami, na przykładzie Korei Północnej i Południowej. Badanie ma charakter empiryczny i stanowi studium przypadku ukierunkowane z jednej strony na zaproponowanie uogólnień dotyczących dyplomacji sportowej państw, z drugiej na zidentyfikowanie cech charakterystycznych dyplomacji sportowej pomiędzy dwoma państwami koreańskimi. Podjęta została także próba weryfikacji hi- 
potezy, zgodnie z którą sport może być postrzegany jako obszar, w ramach którego przedstawiciele skonfliktowanych państw są w stanie podjąć dialog, nawet jeśli w innej sytuacji nie byłoby to możliwe.

Na podstawie przeprowadzonego badania wspominana hipoteza została uprawdopodobniona. Zaobserwowano, że dyplomacja sportowa pomiędzy Koreą Północną i Południową była realizowana przy wykorzystaniu szeregu metod, takich jak wymiany sportowe, negocjacje dotyczące współpracy sportowej w tym wspólnego uczestnictwa w wydarzeniach sportowych oraz wykorzystanie imprez sportowych jako okoliczności dla zaaranżowania politycznych rozmów, co wydaje się stanowić cechę charakterystyczną badanego przypadku. Zaobserwowano także fluktuacje intensywności współpracy w dziedzinie sportu, które były uzależnione od aktualnego stanu stosunków politycznych pomiędzy krajami, aczkolwiek z drugiej strony w niektórych sytuacjach sport pozwalał stronom rozwijać zbliżenie polityczne. Efektywność dyplomacji sportowej pomiędzy Koreą Północną i Południową została zatem oceniona jako ograniczona, ale zauważalna.

Słowa kluczowe: Korea Północna, Korea Południowa, dyplomacja sportowa, dyplomacja publiczna, polityka i sport.

DOI: $10.7862 /$ rz.2018.hss.74

Tekst złożono do redakcji: lipiec $2016 \mathrm{r}$.

Tekst przyjęto do druku: grudzień $2018 \mathrm{r}$. 
